\title{
PENGARUH PERINGKAT, LIKUIDITAS, KUPON DAN MATURITAS TERHADAP YIELD OBLIGASI PADA BURSA EFEK INDONESIA (BEI) PERIODE 2013-2014
}

\author{
Neneng Susanti ${ }^{1}$ dan Muhamad Ruri Permana ${ }^{2}$ \\ ${ }^{1}$ Jurusan Bisnis dan Manajemen, Universitas Widyatama Bandung \\ neneng.susanti@widyatama.ac.id \\ 2 Jurusan Bisnis dan Manajemen, Universitas Widyatama Bandung \\ ruripermana45@gmail.com
}

\begin{abstract}
ABSTRAK
Pasar Modal adalah tempat transaksi jual beli saham dan obligasi yang betrujuan untuk mendapatkan return. Penelitian ini menggunakan peringkat, likuiditas, kupon, dan maturitas obligasi sebagai variabel independent dan yield obligasi sebagai variabel dependentnya. Penelitian ini bertujuan untuk mengetahui seberapa besar pengaruh dari peringkat, likuiditas, kupon, dan maturitas terhadap yield obligasi dari perusahaan-perusahaan yang terdaftar pada BEI periode 2013-2014. Obligasi sendiri ialah surat hutang yang diterbitkan oleh pemerintah ataupun perusahaan swasta kepada investor, dan dimana hutang tersebut harus dibayar pada jangka waktu yang ditentukan. Populasi dalam penelitian ini adalah perusahaan yang terdaftar pada BEI periode 2013-2014 sebanyak 525 perusahaan setelah pemilihan sampel dengan menggunakan teknik purposive sampling diperoleh sampel sebanyak 25 perusahaan dengan 46 jenis obligasi yang terdaftar pada BEI periode 2013-2014 yang diolah dengan menggunakan metode analisis regresi linear berganda dengan menggunakan SPSS versi 23. Penelitian ini memiliki hasil yang menunjukan bahwa secara simultan peringkat, likuiditas, kupon, dan maturitas berpengaruh positif secara signifikan terhadap yield obligasi sebesar 53,8\% dan secara parsial kupon berpengaruh positif secara signifikan terhadap yield obligasi, sedangkan peringkat dan maturitas berpengaruh negatif secara signifikan terhadap yield obligasi lalu untuk variabel likuiditas memiliki hasil yang tidak berpengaruh dan tidak signifikan terhadap yield obligasi.
\end{abstract}

Kata Kunci: Yield Obligasi, Peringkat Obligasi, Likuiditas Obligasi, Kupon Obligasi, Maturitas Obligasi.

\section{PENDAHULUAN}

Terdapat dua jenis instrumen didalam pasar modal yaitu saham dan obligasi. Saham memiliki return berupa dividen pertahun apabila perusahaan tersebut memiliki kebijakan untuk membagikan dividennya namun dapat juga berupa capital gain, sedangkan obligasi memiliki return berupa kupon yang diperoleh pemegang obligasi yang periode pembayarannya dapat berbeda-beda (Suryana, 2016). Obligasi merupakan alternatif bagi investor yang kurang menyukai resiko dalam berinvestasi, didalam pasar modal obligasi merupakan sesuatu yang sangat menguntungkan dibandingkan dengan pinjaman bank, karena pembayaran bunga pada obligasi lebih rendah dan dapat dibayar secara berkala, 6 bulan atau setahun (Sinulingga, 2014). Obligasi sendiri adalah surat hutang yang dikeluarkan oleh perusahaan pemerintah maupun swasta kepada investor yang memiliki nominal tertentu dan hutang tersebut harus dibayarkan pada masa yang ditentukan, dan investor akan mendapatkan keuntungan berupa bunga. Obligasi konvensional yang berasal dari perusahaan pada BEI tahun 2013 hingga 2014 dipilih untuk menjadi objek pada penelitian ini. Yield Obligasi harus diperhatikan oleh investor yang akan menginvestasikan dananya pada obligasi, karena yield obligasi selain sebagai return dapat juga memberikan informasi besar atau kecilnya keuntungan yang akan didapatkan oleh investor tersebut. Yield to maturity ialah yield yang sering digunakan sebagai alat informasi. Sebagai berikut adalah grafik yang menunjukan pergerakan yield obligasi dari perusahaan yang terdaftar di BEI tahun 2010 hingga 2014: 


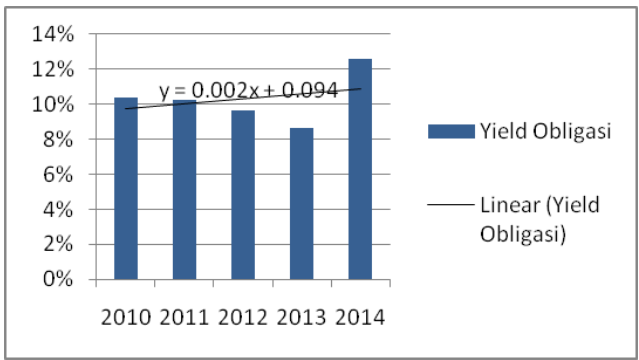

Gambar 1. Pergerakan Yield Obligasi tahun 2010-2014

Sumber: IBMD, hasil pengolahan 2016.

Berdasarkan Gambar 1, pergerakan yield obligasi tahun 2010 hingga 2014 mengalami pergerakan yang tidak konstan, pada tahun 2013 mengalami penurunan dari tahun sebelumnya hal tersebut sejalan dengan artikel yang dimuat pada www.ibpa.co.id oleh Satriani Wahyu dan Dina Farisah yang menjelaskan bahwa, berdasarkan laporan Asian Development Bank (ADB), pada periode tersebut return obligasi Indonesia terkoreksi 17,8\%. Penurunan return terjadi karena harga obligasi meningkat dan membuat obligasi tersebut tidak dilirik oleh investor yang menyebabkan capital gain yang diperoleh investor menjadi berkurang, hal tersebut lebih menjelaskan penyebab dari yield obligasi pada BEI menurun dari tahun sebelumnya. Kenaikan yield terjadi pada tahun 2014 yang disebabkan salah satunya oleh harga obligasi yang menurun dan berpengaruh terhadap peningkatan yield obligasi, kenaikan tingkat yield obligasi berjangka waktu sepuluh tahun ini menuju kenaikan bulanan terbesar sejak januari, hal tersebut dijelaskan pada halaman www.ibpa.co.id oleh Taqiyyah Barratut. Tingkat yield obligasi yang akan diterima oleh investor tersebut akan mengalami perubahan seiring dengan perubahan kondisi perekonomian baik secara mikro maupun makro. Hasil dari yield obligasi tersebut, mencerminkan kinerja dari suatu obligasi yang nantinya berguna sebagai informasi dalam pengambilan keputusan oleh investor. Oleh karena itu, baik investor ataupun emiten harus memperhatikan fluktuasi yield obligasi dan harus melihat faktor-faktor eksternal dan internal yang mempengaruhinya. Disebabkan oleh semua hal yang sudah dipaparkan, peniliti ingin mengetahui faktor-faktor apasaja yang mempengaruhi yield obligasi itu sendiri dan ingin mencari teori yang akan dapat dipergunakan untuk memecahkan masalah penelitian serta membuktikan hipotesis sementara pada penelitian dengan menggunakan alat statistik yang dipergunakan. Peneliti memilih beberapa faktor dari ekternal maupun internal yang diduga akan mempengaruhi yield obligasi yang akan diteliti pada penelitian ini.

Untuk melakukan investasi pada obligasi selain membutuhkan dana, diperlukan pula pengetahuan yang cukup tentang obligasi itu sendiri serta untuk memperkuatnya diperlukan pula naluri bisnis yang baik untuk menganalisis faktor-faktor yang bisa mempengaruhi investasi pada obligasi tersebut Krisnilasari (2007). Salah satu yang harus diperhatikan oleh investor adalah peringkat obligasi. Peringkat obligasi dikeluarkan oleh suatu lembaga atau agen pemeringkat obligasi yang bertujuan untuk menilai kinerja perusahaan, hal tersebut dapat dimanfaatkan untuk memutuskan apakah obligasi tersebut layak dikeluarkan atau tidak serta mengetahui tingkat risikonya. Selain itu peringkat obligasi bertujuan untuk menilai kinerja perusahaan tersebut dan dapat memberikan informasi tentang kemungkinan keuntungan yang akan diperoleh dan resiko yang harus ditanggungnya. Semakin tinggi peringkat semakin menunjukan Obligasi tersebut terhindar dari risiko default (Indarsih, 2013). Penelitian yang dilakukan oleh Bhojraj dan Sengupta (2003), Khurana dan Raman (2003), Crabtree dan Maher (2009) lalu Ibrahim (2008) serta Surya dan Nasher (2011) menyatakan bahwa terdapat pengaruh negatif dan signifikan peringkat obligasi terhadap yield obligasi yang berarti semakin tinggi peringkat obligasi maka Yield To Maturity obligasi akan semakin kecil. 
Semakin besar tingkat keuntungan yang diinginkan investor (yield to maturity) maka semakin rendah harga obligasi, sebaliknya jika tingkat keuntungan yang diinginkan juga kecil, maka harga obligasi semakin tinggi. Jadi ketika anda mendengar atau membaca informasi bahwa yield (yield to maturity) naik atau turun, itu berarti tingkat keuntungan yang diharapkan untuk obligasi naik atau turun Damena, et al. (2014). Menurut Yuan (2001) Likuiditas obligasi yang tinggi akan menyebabkan obligasi lebih menarik karena tersedianya pembeli dan penjual yang lebih banyak sehingga pihak yang memiliki obligasi dapat menjual obligasinya kapan saja. Menurut Nurfauziah dan Setyarini (2004) Likuiditas mempunyai pengaruh signifikan terhadap Yield to Maturity, Likuiditas dapat menjadi cerminan dari pertimbangan investor untuk berinvestasi pada obligasi perusahaan.

Menurut Damena, et al. (2014) kupon adalah berupa pendapatan suku bunga yang diterima oleh pemegang obligasi atas perjanjian dengan penerbit obligasi tersebut. Sebagai berikut adalah pergerakan kupon yang terdapat pada perusahaan yang terdaftar di BEI periode 2013 - 2014:

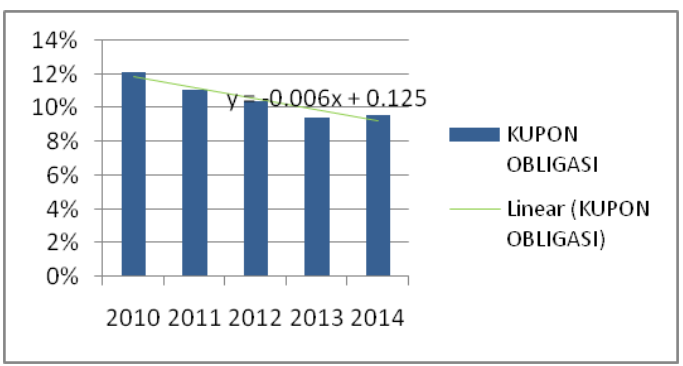

Gambar 2. Pergerakan Kupon Obligasi tahun 2010 - 2014

Sumber: IBMD, hasil pengolahan 2016.

Pada Gambar 2 yaitu Pergerakan Kupon Obligasi tahun 2010-2014 menjelaskan bahwa nilai kupon obligasi setiap tahunnya semakin menurun mulai dari tahun 2010 hingga tahun 2013 namun kembali meningkat pada tahun berikutnya, hal tersebut terjadi dikarenakan perusahaan yang terdaftar di BEI dari tahun ke tahun memiliki tingkat permintaan obligasi yang rendah, yield yang semakin rendah dan tidak dapat menarik investor diakibatkan memiliki kupon yang semakin rendah setiap tahunnya, hal tersebut disimpulkan melalui pernyataan dari Damena, et al. (2014) kupon yang tinggi akan menyebabkan obligasi menarik bagi investor karena nilainya yang tinggi akan memberikan yield yang makin tinggi pula dan diperkuat juga pada penelitian terdahulu (Krisnilasari, 2007; Damena, et al., 2014) yang menyatakan hasil penelitiannya bahwa semakin tinggi tingkat kupon obligasi maka sejalan juga dengan meningkatnya permintaan obligasi dan harganya atau return obligasinya (yield).

Menurut Puhwanto (2014) Maturitas obligasi jumlah jangka waktu atau lamanya perusahaan harus membayar pokok dan bunga kepada pembeli obligasi. Salah satu karakteristik yang akan dipertimbangkan oleh investor sebelum menginvestasikan dananya adalah maturitas obligasi. Tingkat maturitas sebuah obligasi juga bisa menjadi faktor penting dalam mengetahui besaran yield obligasi yang akan diperoleh oleh seorang investor Aisah (2014). Sebagai berikut adalah pergerakan maturitas obligasi dari tahun 2010 hingga 2014 pada perusahaan yang terdaftar di BEI yang sertai dengan penjelasannya: 


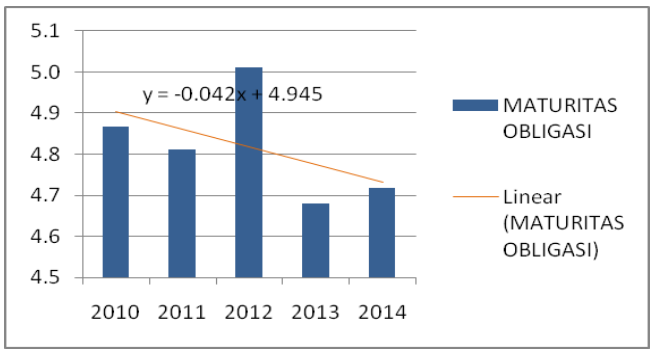

Gambar 3. Pergerakan Maturitas Obligasi tahun 2010-2014

Sumber: IBMD, hasil pengolahan 2016.

Berdasarkan gambar 3 dapat dilihat maturitas mengalami penurunan dari tahun 2010 ke 2011 namun pada tahun berikutnya mengalami peningkatan kembali lalu disusul dengan penurunan serta disusul kembali dengan peningkatan yang tidak begitu berbeda dengan sebelumnya, hal tersebut membuktikan bahwa maturitas adalah memang sebagai salah satu acuan investor sebelum menginvestasikan dananya. Pada saat umur obligasi singkat atau pada saat menurun apabila dilihat dari grafik diatas disanalah investor menginvestasikan dananya dan sebaliknya ketika umur obligasi yang panjang atau mengalami peningkatan apabila dilihat dari grafik diatas disanalah investor berfikir ulang untuk menginvestasikan dananya. Terdapat beberapa penelitian yang menyebutkan umur obligasi berpengaruh positif terhadap yield obligasi, penelitian tersebut adalah (Bhojraj dan Sengupta, 2003; Sam'ani, 2008; Surya dan Nasher, 2011). Dapat dilihat dari berbagai fenomena di atas peringkat obligasi, likuiditas obligasi, kupon obligasi, dan maturitas obligasi harus diperhatikan terlebih dahulu oleh seorang investor sebelum menginvestasikan dananya, karena pada akhirnya juga akan mempengaruhi yield obligasi yang akan didapat oleh investor itu sendiri. Berdasarkan penjelasan di atas, peneliti ingin membuktikan hipotesis bahwa apakah peringkat obligasi, likuiditas obligasi, kupon obligasi, dan maturitas obligasi berpengaruh terhadap yield obligasi.

\section{METODE PENELITIAN}

Objek yang digunakan untuk penelitian ini yaitu peringkat, likuiditas, kupon, maturitas, dan yield obligasi pada perusahaan konvensional yang mengeluarkan obligasi dan terdaftar di Bursa Efek Indonesia (BEI) pada periode 2013 - 2014. Adapun populasi pada penelitian ini adalah seluruh perusahaan yang terdaftar di Bursa Efek Indonesia (BEI) periode 2013-2014 dengan berjumlah 525 perusahaan. Setelah melalui tahap purposive sampling atau tahap pertimbangan tersebut maka diperoleh sampel sebanyak 25 perusahaan dengan 46 jenis obligasi. Sumber data dalam penelitian ini merupakan data sekunder sedangkan jenis data yang digunakan dalam penelitian adalah data kuantitatif, dimana data ini dalam bentuk angka yang dapat dihitung. Adapun sumber data yang diperoleh melalui Indonesian Bond Market, website www.idx.co.id, www.bi.go.id, www.pefindo.com , www.ibpa.co.id , www.republika.co.id dan Informasi lain yang diperoleh dari sumber kepustakaan berupa jurnal yang berhubungan dengan keuangan, textbook, media elektronik.

Pengukuran variabel yield obligasi dengan menggunakan rumus YTM atau yield to maturity, lalu untuk variabel independentnya mulai dari peringkat obligasi dengan menggunakan indikator peringkat yang dikeluarkan oleh PT. Pefindo seperti AAA, BBB, BB, B, CCC, D serta agar sama bentuknya untuk diolah digunakan skala ordinal berdasarkan peringkat tersebut dengan kode 1-8, lalu indikator untuk likuiditas obligasi dengan frekuensi obligasi yang sudah diperdagangkan, kupon obligasi menggunakan presentase yang diukur dengan menggunakan kupon yang dberikan 
oleh emiten obligasi, yang terahir adalah maturitas obligasi menggunakan satuan tahun sesuai dengan masa jatuh tempo obligasi tersebut.

Metode analisis dalam penelitian ini menggunakan model regresi linier berganda dengan bantuan program SPSS versi 23. Cara ini ditempuh mengingat pengolahan data dengan program tersebut lebih cepat dan tepat untuk pengolahan regresi berganda dan memiliki tingkat ketelitian yang tinggi dibandingkan dengan perhitungan secara manual. Adapun tahapan yang dilakukan dalam penelitian ini sebagai berikut: 1) Uji Asumsi Klasik dengan beberapa uji yaitu uji normalitas kolmogorov smirnov, uji multikolinearitas dengan melihat nilai tolerance dan VIFnya, lalu uji autokolerasi dengan menggunakan uji durbin-watson, serta yang terakhir uji heteroskedastisitas dengan menggunakan uji glejser 2) Analisis Korelasi dan Koefisien Determinasi 3) Analisis Regresi Berganda 4) Pengujian Hipotesis dengan Uji F dan Uji T.

\section{HASIL DAN PEMBAHASAN}

Pada umumnya penelitian yang baik adalah penelitian yang sudah dinyatakan lolos dari uji asumsi klasik, uji yang pertama dilakukan pada penelitian ini adalah uji asumsi klasik yang mengindikasi bahwa data data yang diolah pada peneltian ini adalah valid. Hasil uji normalitas yang dilakukan ialah memenuhi asumsi normalitas, hasil uji multikoleniaritas menyebutkan bahwa data data yang diuji tidak terjadi kolerasi pada nilai tolerance dan VIFnya, lalu hasil autokolerasi menyatakan diindikasikan tidak ada autokolerasi pada penelitian ini, serta pada hasil uji heteroskedastisitas menyimpulkan tidak terjadi heteroskedastisitas pada model regresi penelitian ini atau dikatakan homoskedastisitas.

Berdasarkan hasil analisis kolerasi dan koefesien determinasi dapat dilihat besar nilai kolerasinya atau besar nilai $\mathrm{r}$ nya adalah 0,733 nilai tersebut berada diantara 0,60-0,799 dengan demikian artinya adalah kolerasi pada penelitian ini mempunyai tingkat hubungan yang kuat. Untuk nilai koefesien determinasinya atau nilai $\mathrm{r}$ squarenya sebesar 0,538 atau $53,8 \%$, hal tersebut membuktikan bahwa pada penelitian ini variabel independent memiliki pengaruh sebesar 53,8\% terhadap variabel dependentnya dan sisanya yaitu 47,2\% dipengaruhi oleh faktor lain yang tidak diteliti dalam penelitian ini.

Analisis regresi berganda bertujuan untuk mengetahui regresi linear berganda hubungan peringkat, likuiditas, kupon, maturitas terhadap yield obligasi, dapat dilihat pada tabel sebagai berikut:

$\mathrm{Y}=7,708+(-0,399) \mathrm{X}_{1}+(-0,002) \mathrm{X}_{2}+2,287 \mathrm{X}_{3}+(-1,183) \mathrm{X}_{4}+\varepsilon$

$\mathrm{Y}=$ Yield Obligasi, $\mathrm{X}_{1}=$ Peringkat Obligasi, $\mathrm{X}_{2}=$ Likuiditas Obligasi, $\mathrm{X}_{3}=$ Coupon Obligasi,

$\mathrm{X}_{4}=$ Maturitas Obligasi, dan $\varepsilon=$ error

\section{Hasil dari Pengaruh Peringkat, Likuiditas, Kupon, dan Maturitas terhadap Yield Obligasi}

Hasil penelitian secara simultan dapat diliat melalui hasi Uji F yang bertujuan untuk mengetahui signifikansi pengaruh variabel peringkat obligasi $\left(\mathrm{X}_{1}\right)$, likuiditas obligasi $\left(\mathrm{X}_{2}\right)$, kupon obligasi $\left(\mathrm{X}_{3}\right)$, dan maturitas obligasi $\left(\mathrm{X}_{4}\right)$ secara simultan terhadap yield obligasi (Y) Adapun hasil Uji $\mathrm{F}$ yang telah diolah oleh peneliti sebagai berikut: 
Tabel 1. Hasil Uji F (Simultan)

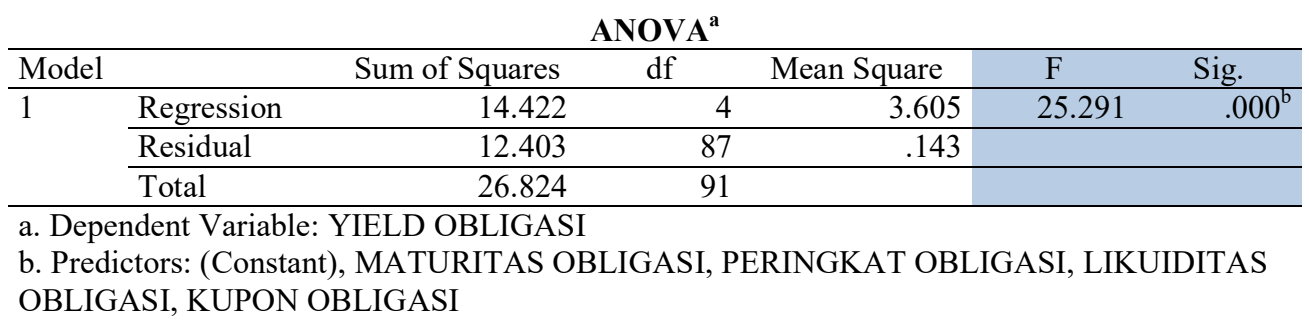

Berdasarkan hasil dari penelitian ini adalah peringkat, likuiditas, kupon, dan maturitas berpengaruh secara bersama-sama terhadap yield obligasi. Dimana dari nilai signifikansi yang dihasilkan lebih kecil dari 0,05 yaitu sebesar 0,000 dan memiliki nilai $\mathrm{F}_{\text {hitung }}$ sebesar 25,291. Penelitia ini pun membuktikan bahwa variabel independent memiliki pengaruh sebesar 53,8\% terhadap variabel dependentnya dan sisanya yaitu $47,2 \%$ dipengaruhi oleh faktor lain yang tidak diteliti dalam penelitian ini. Hasil dari penelitian ini sesuai dengan penelitian yang dilakukan oleh Desnitasari (2014) yang menyatakan bahwa Secara simultan, tingkat suku bunga, peringkat obligasi memberikan pengaruh yang signifikan terhadap Yield To Maturity (YTM) obligasi korporasi yang terdaftar di BEI Periode 2010-2012. Hasil penelitian lain juga mendukung hasil penelitian ini yang dilakukan oleh Indarsih (2014) yang mengatakan bahwa variabel bebas dalam penelitiannya yaitu tingkat suku bunga SBI, rating, likuiditas dan maturitas secara bersama-sama berpengaruh terhadap variabel terikat (Yield To Maturity). Penelitian terdahul yang mendukung hasil penelitian ini adalah Ibrahim (2008) mengatakan bahwa variabel independen (Peringkat Obligasi) secara bersama-sama berpengaruh terhadap variabel dependen (YTM). Berikut adalah hasil dari

Setelah Uji F maka dilakukan uji berikuynya yaitu Uji $\mathrm{T}$ yang dilakukan untuk mengetahui seberapa besar pengaruh masing-masing komponen variabel independen terhadap variabel dependen. Dengan menggunakan tingkat signifikansi sebesar 5\% yang dinilai cukup mewakili hubungan antara variabel-variabel yang diteliti dan merupakan tingkat signifikansi yang umum digunakan didalam penelitian ilmu sosial. Adapun hasil Uji T yang telah diolah oleh peneliti sebagai berikut:

Tabel 2. Hasil Uji T (Parsial)

\begin{tabular}{|c|c|c|c|c|c|c|}
\hline \multicolumn{7}{|c|}{ Coefficients $^{\mathrm{a}}$} \\
\hline & & Unstandardize & Coefficients & $\begin{array}{l}\text { Standardized } \\
\text { Coefficients }\end{array}$ & & \\
\hline \multicolumn{2}{|c|}{ Model } & $\mathrm{B}$ & Std. Error & Beta & $\mathrm{t}$ & Sig. \\
\hline \multirow[t]{5}{*}{1} & (Constant) & 7.708 & 1.109 & & 6.949 & .000 \\
\hline & $\begin{array}{l}\text { PERINGKAT } \\
\text { OBLIGASI }\end{array}$ & -.399 & .074 & -.403 & -5.420 & .000 \\
\hline & $\begin{array}{l}\text { LIKUIDITAS } \\
\text { OBLIGASI }\end{array}$ & -.002 & .002 & -.114 & -1.542 & .127 \\
\hline & KUPON OBLIGASI & 2.287 & .383 & .540 & 5.973 & .000 \\
\hline & $\begin{array}{l}\text { MATURITAS } \\
\text { OBLIGASI }\end{array}$ & -1.183 & .144 & -.736 & -8.205 & .000 \\
\hline
\end{tabular}

a. Dependent Variable: YIELD OBLIGASI 


\section{Pengaruh Peringkat terhadap Yield Obligasi}

Penelitian ini menunjukan hasil bahwa peringkat obligasi berpengaruh negatif secara signifikan terhadap yield obligasi, berdasarkan hasil dari $\mathrm{T}_{\text {hitung }}-5,420$ serta nilai signifikan dari hasil $\mathrm{Uji} \mathrm{T}$ sebesar 0,000 yang artinya $<0,05$. Begitupun berlaku sebaliknya. Hasil penelitian ini diperkuat dengan hasil dari penelitian Ibrahim (2008) yang menyatakan bahwa terdapat pengaruh negatif dan signifikan antara peringkat obligasi terhadap yield obligasi diterima. Diperkuat kembali oleh penelitian Desnitasari (2014) yang mempunyai hasil peringkat obligasi menunjukkan bahwa terdapat pengaruh negatif dan signifikan terhadap yield obligasi. Disusul juga oleh (Sam'ani, 2009; Surya \& Nasher, 2011; Ayu Purnamawati, 2013; Sari \& Nyoman Abundanti, 2015) yang mengemukakan bahwa peringkat Oobligasi memiliki pengaruh negatif dan signifikan terhdap yield obligasi. Tetapi adapula penelitian yang tidak sesuai yang dilakukan oleh Nurfauziah dan Setyarini (2004) dan Indarsih (2013) yang menunjukkan bahwa peringkat obligasi tidak berpengaruh terhadap yield obligasi yang didasari oleh hasil penelitian yang menunjukan $\mathrm{H}_{0}$ diterima.

\section{Pengaruh Likuiditas terhadap Yield Obligasi}

Pada penelitian ini memiliki hasil likuiditas obligasi tidak berpengaruh terhadap yield obligasi dikarenakan $T_{\text {hitung }}$ untuk variabel Likuiditas Obligasi sebesar -1,542 dan apabila dibandingkan dengan $\mathrm{T}_{\text {tabel }}$ yang sudah didapatkan oleh peneliti sebesar 1,98793 maka artinya $-1,98793<-$ $1,542<1,98793$ serta nilai signifikan dari hasil Uji $\mathrm{T}$ sebesar 0,127 yang artinya $>0,05$. Hasil dari penelitian ini bertolak belakang denga hasil penelitian Nurfauziah dan Setyarini (2004) serta Yan He, et al. (2005) yang menjelaskan hasil penelitiannya yaitu mengatakan bahwa likuiditas berpengaruh positif terhadap Yield To Maturity. Hasil penelitian ini juga bertolak belakang dengan penelitian yang dilakukan oleh Favero et al. (2007) yang menyatakan bahwa likuiditas berpengaruh negatif terhadap yield obligasi didasari oleh hasil penelitian yang menunjukan $\mathrm{H}_{0}$ ditolak. Adapun penelitian yang serupa dengan mengatakan hasil likuiditas tidak berpengaruh terhadap Yield To Maturity oleh Indarsih (2013).

\section{Pengaruh Kupon terhadap Yield Obligasi}

Hasil dari penelitian ini yang sudah dijelaskan sebelumnya, menunjukan kupon obligasi berpengaruh postif secara signifikan terhadap yield obligasi hal tersebut terjadi dikarenakan $\mathrm{T}_{\text {hitung }}$ untuk variabel kupon obligasi sebesar 5,973 dan apabila dibandingkan dengan $\mathrm{T}_{\text {tabel }}$ yang sudah didapatkan oleh peneliti sebesar 1,98793 maka artinya 5,973 > 1,98793 serta nilai signifikan dari hasil Uji T sebesar 0,000 yang artinya $<0,05$. Begitupun berlaku sebaliknya. Hasil dari penelitian ini diperkuat oleh penelitian terdahulu (Krisnilasari, 2007; Damena, et. al., 2014) yang menyatakan bahwa semakin tinggi tingkat kupon obligasi maka akan semakin tinggi permintaan obligasi dan tingkat perubahan harganya atau return obligasinya (yield). Yield yang semakin rendah dan tidak dapat menarik investor diakibatkan memiliki kupon yang semakin rendah setiap tahunnya, hal tersebut disimpulkan melalui pernyataan dari Damena, et. al. (2014). Maka dari itu kupon memiliki pengaruh dengan yield karena nilai kupon yang tinggi akan menarik minat investor karena dengan nilai kupon yang tinggi akan memberikan yield yang makin tinggi pula. jika kupon obligasi tersebut cukup tinggi maka harga obligasi akan cenderung semakin meningkat. 


\section{Pengaruh Maturitas terhadap Yield Obligasi}

Hasil penelitian yang sudah dilakukan oleh peneliti maka disimpulkan bahwa maturitas obligasi berpengaruh negatif secara signifikan terhadap yield obligasi, hal tersebut terjadi berdasarkan $\mathrm{T}_{\text {hitung }}$ untuk variabel Maturitas Obligasi sebesar -8,205 dan apabila dibandingkan dengan $\mathrm{T}_{\text {tabel }}$ yang sudah didapatkan oleh peneliti sebesar 1,98793 maka artinya $-9,071<-8,205$ serta nilai signifikan dari hasil Uji T sebesar 0,000 yang artinya $<0,05$. Begitupun berlaku sebaliknya. Hasil penelitian ini sejalan dengan hasil penelitian oleh Nurfauziah \& Adistien (2004) yang menyatakan bahwa maturitas berpengaruh negatif secara signifikan terhadap yield obligasi. Lalu adapun yang mempunyai hasil penelitian serupa tetapi tidak memiliki pengaruh yaitu Puhwanto (2014) yang menyatakan bahwa maturitas atau umur obligasi tidak berpengaruh terhadap yield obligasi. Adapun penelitian yang bertolak belakang dengan hasil penelitian ini antara lain penelitian dari (Khurana dan Raman, 2003; Surya dan Nasher, 2011; Desnitasari, 2014; Sari \& Nyoman Abundanti, 2015) yang menyatakan bahwa maturitas berpengaruh positif terhadap Yield To Maturity obligasi. Hal tersebut sejalan dengan apa pendapat Arifin (2007:133) yang menunjukkan bahwa kurva yield dalam penelitian ini memiliki slope yang mengarah ke kanan atas (Normal Yield Curve) yang mencerminkan kondisi normal dimana obligasi berjatuh tempo pendek memiliki Yield To Maturity yang lebih rendah dibandingkan dengan obligasi berjatuh tempo panjang. Dengan demikian untuk berinvestasi jangka panjang umumnya investor mensyaratkan adanya nilai lebih (premium).

\section{KESIMPULAN}

1. Berdasarkan dari hasil Uji $F$ atau hasil pengujian secara simultan terbukti bahwa peringkat, likuiditas, kupon, dan maturitas berpengaruh positif secara signifikan terhadap yield obligasi pada BEI periode 2013-2014 yang artinya apabila nilai dari kelima variabel independent tersebut meningkat maka akan disusul oleh peningkatan pula dari nilai variabel dependent-nya dengan diikuti tingkat kebenaran dan begitupun sebaliknya serta seluruh variabel independent memiliki pengaruh memiliki pengaruh sebesar 53,8\% terhadap variabel dependentnya dan sisanya 47,2\% dipengaruhi oleh variabel lainnya yang tidak diteliti.

2. Berdasarkan dari hasil Uji $\mathrm{T}$ atau hasil pengujian secara parsial terbukti bahwa peringkat berpengaruh negatif secara signifikan terhadap yield obligasi pada BEI periode 20132014 yang artinya bahwa apabila nilai dari peringkat meningkat maka akan disusul oleh penurunan dari nilai yield obligasi dengan diikuti tingkat kebenaran dan begitupun sebaliknya.

3. Berdasarkan dari hasil Uji $\mathrm{T}$ atau hasil pengujian secara parsial terbukti bahwa likuiditas tidak berpengaruh secara tidak signifikan terhadap yield obligasi pada BEI periode 2013 2014 yang artinya bahwa apabila nilai dari likuiditas meningkat maka tidak akan disusul oleh peningkatan maupun penurunan dari nilai yield obligasi dengan tidak diikuti pula tingkat kebenaran.

4. Berdasarkan dari hasil Uji $\mathrm{T}$ atau hasil pengujian secara parsial terbukti bahwa kupon berpengaruh positif secara signifikan terhadap yield obligasi pada BEI periode 2013-2014 yang artinya bahwa apabila nilai dari kupon meningkat maka akan disusul oleh peningkatan dari nilai yield obligasi dengan diikuti tingkat kebenaran dan begitupun sebaliknya.

5. Berdasarkan dari hasil Uji $\mathrm{T}$ atau hasil pengujian secara parsial terbukti bahwa maturitas berpengaruh negatif secara signifikan terhadap yield obligasi pada BEI periode 2013- 
2014 yang artinya bahwa apabila nilai dari maturitas meningkat maka akan disusul oleh penurunan dari nilai yield obligasi dengan diikuti tingkat kebenaran dan begitupun sebaliknya.

\section{REFERENSI}

Arifin. 2007. Teori keuangan dan Pasar modal. Ekonisia. Yogyakarta.

Khurana, I. K. dan Raman, K.K. 2003. Are Fundamentals Priced in the Bond Market. Contemporary Accounting Research, Fall, 465-494.

Crabtree, A; dan J.J. Maher. 2009. The Influence of Differences in Taxable Income and Book Income on the Bond Credit Market. The Journal of the American Taxation Association 31 (1): $75-110$.

Suryana, Robbyansyah. 2016. Pengaruh Likuiditas Obligasi, Maturity, dan Coupon terhadap Harga Obligasi pada Bursa Efek Indonesia Periode 2013 - 2014. Skripsi. FBM Universitas Widyatama.

Sinulingga, David Kurniansyah. 2014. Analisis Pengaruh Rating, Likuiditas dan Maturitas terhadap Yield to Maturity. Skripsi. FE Universitas Sumatera Utara.

Satriani, Wahyu dan Dina Farisah. 2013. Return obligasi RI jatuh makin dalam. Diambil dari: ibpa.co.id/News/ArsipBerita/tabid/126/EntryId/5532/Return-obligasi-RI-jatuh-makindalam.aspx

Taqiyyah, Barratut. 2013. Yield obligasi tertekan, rupiah semakin loyo. Diambil dari: ibpa.co.id/News/ArsipBerita/tabid/126/EntryId/5689/Yield-obligasi-tertekan-rupiahsemakin-loyo.aspx

Krisnilasari, Monica. 2007. Analisis Pengaruh Likuiditas Obligasi, Coupon dan Jangka Waktu Jatuh Tempo Obligasi Terhadap Harga Obligasi di Bursa Efek Surabaya. Tesis S-2. Pasca Sarjana, Universitas Diponegoro.

Indarsih, Nanik. 2013. Pengaruh Tingkat Suku Bunga SBI, Rating, Likuiditas dan Maturitas terhadap Yield to Maturity Obligasi. Jurnal Ilmu Manajemen Volume 1 Nomor 1 Januari 2013 Fakultas Ekonomi Universitas Negeri Surabaya.

Bhojraj dan Sengupta, 2003, "Effect of Corporate Governance on Bond Ratings and Yields: The Role of Institusional Investor and Outside Directors", The Journal of Business, Vol. 76, No. 3, Hal. 455-475.

Ibrahim, Hadiasman. 2008. Pengaruh Tingkat Suku Bunga, Peringkat Obligasi, Ukuran Perusahaan dan DER Terhadap Yield To Maturity Obligasi Korporasi di BEI Periode 2004-2006. Tesis. (http://www.eprints.undip.ac.id/17480).

Surya dan Nasher. 2011. Analisis Pengaruh Tingkat Suku Bunga SBI, Exchange Rate, Ukuran Perusahaan, Debt To Equity Ratio dan Bond Rating terhadap Yield Obligasi Korporasi di Indonesia. Jurnal Manajemen Teknologi. Volume 10 Number 2.

Damena, Herdy, Ervita Safitri, dan Rini Aprilia. 2014. Analisis Pengaruh Coupon(Bunga Obligasi), Jangka Waktu Jatuh Tempo, dan Liquiditas Obligasi terhadap Tingkat Perubahan Harga Obligasi yang terdaftar di Bursa Efek Indonesia. Jurusan Manajemen STIE MDP.

Yuan, Kathy (2001), "The Liquidity Service of Sovereign Bonds", Working Paper, didownload dari www.papers.ssrn.com

Nurfauziah dan Setyarini, Adistien Fatma.2004. Analisis Faktor-Faktor yang Mempengaruhi Yield Obligasi perusahaan (Studi Kasus Pada Industri Perbankan dan Industri Finansial).Jurnal Siasat Bisnis, 2 (9), pp:241-256. 
Puhwanto, Mei Darto Agus. 2014. Analisis Faktor-faktor yang Mempengaruhi Yield Obligasi pada Perusahaan Manufaktur yang terdaftar di Bursa Efek Indonesia Periode 20092912. Skripsi. FB Universitas Katolik Widya Mandala, Surabaya.

Aisah, Siti Hatanty. 2014. Analisis Faktor-faktor Mempengaruhi Yield Obligasi Korporasi. Skripsi. FEB Universitas Dipenogoro, Semarang.

Desnitasari, Isnaini. 2014. Pengaruh Tingat Suku Bunga, Peringkat Obligasi, Ukuran Perusahaan, dan Debt to Equity Ratio terhadap Yield to Maturity. Jurnal. MBTI Universitas Telkom.

Sam'ani. 2008. Pengaruh Good Corporate Governance dan Leverage Terhadap Kinerja Keuangan Pada Perbankan Yang Terdaftar di Bursa Efek Indonesia (BEI) tahun 2004 2007. Tesis Magister Manajemen Universitas Diponegoro.

Ayu Purnamawati, I.G.A. 2013. Pengaruh Peringkat Obligasi, Tingkat Suku Bunga Sertifikat Bank Indonesia, Rasio Leverage, Ukuran Perusahaan dan Umur Obligasi pada Imbal Hasil Obligasi Korporasi di Bursa Efek Indonesia. Jurnal Akuntansi Program Diploma III ISSN 2337-537X, 2 (1), pp: 28-45.

Indarsih, Nanik. 2013. Pengaruh Tingkat Suku Bunga SBI, Rating, Likuiditas dan Maturitas terhadap Yield to Maturity Obligasi. Jurnal Ilmu Manajemen Volume 1 Nomor 1 Januari 2013 Fakultas Ekonomi Universitas Negeri Surabaya.

Favero, et al. 2007. How Does Liquidity Affect Government Bond Yields?. Working Paper No. 181 .

Yan, He at al. 2005. Liquidity, Information Risk, and Asset Pricing: Evidence from the U.S. Government Bond Market, Jurnal SSRN 687523 (Online).

Sari, Ni Wayan Linda Naluritha dan Nyoman Abundanti. 2015. Variabel - varianel yang Mempengaruhi Yield Obligasi pada Perusahaan yang terdafar di Bursa Efek Indonesia. E-Jurnal Manajemen Unud, Vol. 4, No. 11, 2015: 3796-3824.

Khurana, I. K. dan Raman, K.K. 2003. Are Fundamentals Priced in the Bond Market. Contemporary Accounting Research, Fall, 465-494. 